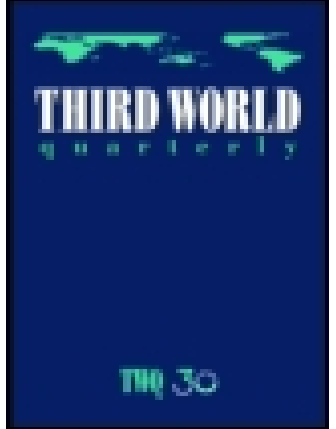

Third World Quarterly

\title{
Global Disorder and the Limits of 'Dialogue'
}

\section{Jeremy Salt}

To cite this article: Jeremy Salt (2008) Global Disorder and the Limits of 'Dialogue', Third World Quarterly, 29:4, 691-710, DOI: 10.1080/01436590802052599

To link to this article: http://dx.doi.org/10.1080/01436590802052599

曲 Published online: 08 May 2008.

Submit your article to this journal $\pi$

Џ Article views: 132

Q View related articles $\widetilde{ }$

47 Citing articles: 1 View citing articles 준 


\section{Global Disorder and the Limits of 'Dialogue'}

\section{JEREMY SALT}

AbSTRACT Since 2001 (designated as the UN Year of Dialogue Among Civilisations) several initiatives have been developed as a means of resolving problems whose causes have been ascribed, primarily by Samuel Huntington and Bernard Lewis, to civilisational difference. This article questions responses to the 'clash of civilisations' thesis which seem to accept the postulates on which it is based. It suggests that while dialogue is an indispensable tool of social cohesion, the source of many of the problems that pose a continuing threat to regional and global order is not 'civilisational difference' but the failure of governments to comply with international laws and conventions they have sworn to uphold. The explanation that 'civilisational difference' is the root cause of global disorder allows them to sidestep responsibility for the consequences of their own policies. Manipulation of the United Nations at the level of the Security Council is further evidence that the answer to global problems lies in redressing the failings of an entrenched world system that is based far more on power and state perceptions of self-interest than justice. The clearest evidence of structural weakness in the international system is to be found in the Middle East, where the UN Secretary-General's former special representative to the 'peace process', Alvaro de Soto, has drawn attention to the disjunction between public declarations of good intentions and high-level manipulation of this 'process' by powerful actors from behind the scenes. The article concludes that where dialogue is not the problem, it cannot be the solution.

The debate over the root causes of global instability has continued without let-up since the bombing of the World Trade Centre on 11 September 2001. The extent to which instability is actually global in nature obviously varies according to how and by whom it is being interpreted. In the dominant leftist narrative, it is the inevitable secondary outcome of the structural violence built into, implied and to a degree tacitly sanctioned by a world system built on power. There is certainly no doubt that resentment of the governments and financial institutions of the West and those who are seen as their political clients and regional agents, and are in many cases only able to stay in power through the provision of large amounts of 'foreign aid', is strongly felt across

Jeremy Salt is in the Department of Political Science, Bilkent University, Ankara, Turkey. Email: jeremy@bilkent.edu.tr.

ISSN 0143-6597 print/ISSN 1360-2241 online/08/040691-20 (c) 2008 Third World Quarterly DOI: $10.1080 / 01436590802052599$ 
the developing world. According to the arguments adumbrated by Bernard Lewis and Samuel P Huntington within the context of an actual or looming 'clash of civilisations', however, the economic and political grievances that appear to be the cause of resentment of the West are merely the symptoms of the real cause - civilisational difference. In the historical game of winners and losers, so the argument goes, resentment of the West arises from a civilisational inferiority complex. Nowhere is this more apparent than among Muslims. Lewis is only concerned with 'Islam and the West'. Huntington applies the theory more generally, but makes his most provocative claims (ie what he calls a Muslim 'propensity' for violence) in the same civilisational context as Lewis. The depiction of a Muslim world driven by a deep-seated resentment of the West that is scarcely rational very much suited the purposes of radical US conservatives already planning an aggressive foreign policy resurgence based on 'pre-emptive' or 'counter- anticipatory' military action on a global scale. The 'clash of civilisations' theory neatly exculpated Western governments from the consequences of their actions. If resentment at Western success was the root cause of problems between 'Islam and the West', the source of the problem lay on the Muslim side and it was up to Muslims to get their house in order. The West would help by promoting 'Western values', by supporting 'moderate' Muslim governments and by taking forceful measures to extinguish terrorism at its source.

Few articles intended for a limited readership can have attracted as much general attention as Huntington's 'A clash of civilizations?'. 'Neither in the article nor the book that followed, ${ }^{2}$ however, is there any sustained analysis of the consequences of Western policies as they have been experienced by Muslims. The emphasis is on the social and economic shortcomings of Muslim societies, which Huntington sees as a breeding ground for antiWestern actions. His attribution to Muslims of a 'propensity' for violence is extraordinary against the background of the genocidal destruction directed outwards from 'Christian' Europe from the beginning of the 'age of expansion' in the 15th century up to the present. His reference to 'Islam's bloody borders' fails to take into account that, while the early Muslim states - Arab, Mughal, Seljuq and Ottoman Turk among them - succeeded in imposing borders on surrounding rulers, in the past four centuries it was an ascendant West that imposed borders and a vanquished East that had no option but to accept them (the successful Turkish national resistance to the British and the French after 1918 is a rare exception). ${ }^{3}$

Although the 'clash of civilisations' propelled Huntington to global prominence and 'brand' recognition among many people who had doutbless never heard of him before, the genesis of the phrase lies in the writings of Bernard Lewis. He began developing the theme in the 1950s as a means of explaining (or explaining away) Arab national resistance to imperialism and colonialism. To Lewis the true source of Arab hostility to the West was not Palestine (the 'licensed grievance' as he dismissively describes $i t^{4}$ ) nor British and French policies of occupation and domination played out across the entire region, from the Atlantic coast of Morocco down to the southern tip of the Arabian peninsula, but civilisational 'problems of readjustment' ${ }^{\text {,5 }}$ to a 
triumphant newcomer. Professor Lewis takes his reader into the mind of one 'Arab' to illustrate the suffering of all in the face of Western success:

\begin{abstract}
Even after liberation the intelligent and sensitive Arab cannot but be aware of the continued subordination of his culture to that of the West. His richest resource is oil-but it is found and extracted by Western processes and machines to serve the needs of Western inventions. His greatest pride is his new army - but it uses Western arms, wears Western-style uniforms and marches to Western tunes. His ideas and ideologies even of anti-Western revolt derive ultimately from Western thought. His knowledge even of his own history and culture owes much to Western scholarship. His writers, his artists, his technicians, even his tailors, testify by their work to the continued supremacy of Western civilization - that ancient rival, the conqueror and now the model of the Muslim. Even the gadgets and garments, the tools and amenities of his everyday life are symbols of bondage to an alien and dominant culture which he hates and admires, imitates but cannot share. It is a deeply wounding, deeply humiliating experience. ${ }^{6}$
\end{abstract}

Having summed up the minds of all Arabs by looking into the mind of one, and then speaking for him, a casebook example of the orientalist at work, Lewis advises his readers that 'we' shall be better able to understand the situation if "we view the present discontents of the Middle East not as a conflict between states or nations but as a clash between civilizations' ${ }^{7}$ Three decades later Arab nationalism has been replaced by an Islamic resurgence. The civilisational focus has changed, the ideological focus has changed, the geographical setting has changed from regional to global, but the 'clash' somehow remains the same. There is a mood and a movement afoot, writes Professor Lewis, "far transcending the level of issues and policies and governments that pursue them. This is no less than a clash of civilizationsthat perhaps irrational but surely historic reaction of an ancient rival against our Judeo-Christian heritage, our secular present and the worldwide expansion of both. ${ }^{8}$ On this basis he builds a case for Muslim hatred of the West, the roots of which 'must be sought in the millennial history of relations between Islam and Christendom'. 'In a sense, 'they've been hating us for centuries and it's very natural that they should. You have this millennial rivalry between two world religions and now from their point of view the wrong one seems to be winning., 10

The civilisational theme is scarcely new. British and French invasion of Muslim lands in the 19th century were justified in the name of civilisation and Muslim resistance portrayed as being mad and fanatical. Sir William Muir's observation that 'the sword of Mahomet, and the Coran, are the most stubborn enemies of Civilisation, Liberty and Truth which the world has yet known' was snapped up by the coming generation of Christian polemicists. ${ }^{11}$ This adversarial view has now been reinforced by Huntington and Lewis beneath a globalised modern veneer of references to migration and the generally high unemployment rate among young men in Muslim societies that is supposedly feeding 'Islamic terrorism', the late 20th century 
incarnation of the 'Mohammedan fanaticism' of the 19th. Resentment, anger, rage and hatred have been built into the old discourse of violence, sexuality and power, again setting up an enemy whose hostility has no rational cause, leaving the rational West with no option but to 'defend' itself through military attack abroad and through the introduction at home of draconian measures striking at the heart of 'Western values' in the name of combating terrorism.

The bombing of the World Trade Centre in New York on 11 September 2001 (designated as the UN Year of Dialogue Among Civilisations) was represented in numerous quarters as validating the Lewis-Huntington line. Following a further act of terror, the bombing of Madrid's Atocha railway terminal on 11 March 2004, the Spanish Prime Minister, Jose Luis Rodriguez Zapatero, called for an 'alliance of cultures' that would head off the 'clash of civilisations' by deepening political, cultural and educational relations 'between those who represent the so-called Western world and, in this historic moment, the area of Arab and Muslim countries'. ${ }^{12} \mathrm{Mr}$ Zapatero was joined by Prime Minister Recep Tayyip Erdoğan of Turkey, where in 2003 suicide bombings of the British consulate in Istanbul and other buildings with a Western face (including the HSBC bank) had killed more than 60 people. The strong support of Erdogan had particular importance because of the perception of Turkey as a 'bridge' between east and west, as a country whose Justice and Development Party government represented a 'moderate' form of Islam, and because Turkey was a predominantly Muslim country seeking membership of the EU. The outcome of their initiatives was the formal establishment, in November 2005, of an Alliance of Civilisations. The members of the High-Level Group appointed under the aegis of the United Nations to chart the path ahead included former Iranian president Muhammad Khatami (who had led the way by calling for a 'dialogue of civilisations' in 1998); South Africa's Archbishop Desmond Tutu; former UNESCO Director-General Federico Mayor; Turkish State Minister Mehmet Aydın; former French foreign minister Hubert Vedrine; former InterAmerican Development Bank head Enrique Iglesias; and André Azoulay, an adviser to King Mohammed VI of Morocco.

The Dialogue Among Civilisations and the Alliance of Civilisations were joined in March 2006, by a third major initiative, the Coexistence of Civilisations project established by the Danish research institute Monday Morning, ${ }^{13}$ creating between them a global network of good intentions. In May 2007 Jorge Sampaio was appointed UN High Representative for the Alliance of Civilisations. In January 2008 the UN Secretary-General, Ban Ki Moon, opening a two-day conference of the Alliance in Madrid, declared that 'Never before in our lifetime has there been a more desperate need for constructive and committed dialogue among individuals, among cultures [and] among and between nations'. ${ }^{4}$ In the words of Señor Sampaio, writing ahead of the conference, 'The complex international situation created in the wake of 11 September, as well as other terrorist attacks that have constantly marked this decade, has turned dialogue between civilisations, religions and cultures into a matter of urgency'. ${ }^{15}$ 


\section{European input}

European support for dialogue was strongly driven by European needs. The rapid transformation of European societies from mono- to multiculturalism and the close proximity in the southern and eastern Mediterranean of Muslim states emphasised the need for dialogue within as well as between. The issues affecting the debate over questions of national and European identity included demographics (migration and the generally higher birth rate among European Muslims), terrorism (the bombings of the Madrid and London public transport systems in 2004 and 2005), youth unemployment, multiculturalism, the wearing of the hijab, free speech (raised most notably by the publication in September 2005 of Danish cartoons mocking the Prophet Muhammad, and by the murder in 2004 of the Dutch film maker Theo van Gogh after the screening of his film Submission, which shows verses of the Qu'ran inscribed on the body of a naked woman), the accession negotiations over Turkish membership of the EU and the Pope's speech on the relative merits of Islam and Christianity.

The infuriated reaction of Muslims worldwide to the publication of the Danish cartoons revived memories of the response nearly two decades earlier to the publication of Salman Rushdie's novel The Satanic Verses (revived again in 2007 with the British government's award of a knighthood to the author). Flemming Rose, the cultural affairs editor of the newspaper which published the cartoons, Jyllands-Posten, argued that by commissioning and publishing the cartoons he was seeking to challenge politically correct self-censorship and extend the boundaries of free speech. Furthermore, his intention was to show Muslims that he considered them as Danish as anyone else.

Equal treatment is the democratic way to overcome traditional barriers of blood and soil for newcomers. To me, that means treating immigrants just as I would any other Danes. And that's what I felt I was doing in publishing the 12 cartoons of Mohammed last year. Those images in no way exceeded the bounds of taste, satire and humor to which I would subject any other Dane, whether the queen, the head of the church or the prime minister. By treating a Muslim figure the same way I would a Jewish or Christian icon, I was sending an important message: You are not strangers, you are here to stay, and we accept you as an integrated part of our life. And we will satirize you, too. It was an act of inclusion, not exclusion, an act of respect and recognition. ${ }^{16}$

In fact, it was not quite as straightforward as that. A prophet is not a prime minister or the head of a church and if Danish Muslims really were to be treated the same as other Danes, their rights would surely have to include the right to be protected from what they (not Flemming Rose) decided was not just insulting but blasphemous. The Christian church was built up around graven images. Islam has no church and does not allow the reproduction of images of the Prophet. Furthermore, contrary to Flemming Rose's claim that everyone was up for mockery, it turned out that Jyllands-Posten had previously refused to publish caricatures of Jesus Christ on the grounds that its readers would find them offensive. And finally, the decision to publish the 
cartoons could hardly be disconnected from Flemming Rose's opinions about the 'unpleasant realities' behind Europe's 'failed experiment' with multiculturalism. 'It's time for the Old Continent to face facts and make some profound changes in its outlook on immigration, integration and the coming Muslim demographic surge. After decades of appeasement and political correctness, combined with growing fear of a radical minority prepared to commit serious violence, Europe's moment of truth is here. ${ }^{17}$

In the more stridently Islamophobic view of others (notably the Egyptianborn writer Bat Ye'or and the late Italian journalist Oriana Fallaci but also ultra right- wing political parties in most member countries of the EU), Europe was on the point of self-immolation in a new land mass called 'Eurabia'. The southern Mediterranean littoral was no longer the focal point of Euro-Mediterranean dialogue but an 'exposed flank', ${ }^{18}$ from which Europe was being threatened with inundation through the migration of Muslims looking for work, unwilling to compromise their identity, difficult to assimilate and harbouring among them the agents of jihadi fundamentalism. The suggestion early in 2008 by the Archbishop of Canterbury, Dr Rowan Williams, that aspects of shar'ia law might be introduced into Britain in the interests of social harmony, was followed not just by widespread criticism of what he was thought to be saying but by attacks on 'multiculturalism' in general. ${ }^{19}$ Returning to the civilisational fray early in 2007, Professor Lewis told an audience at the American Enterprise Institute in Washington that the struggle between Islam and Christendom had entered a new stage. ${ }^{20}$ This struggle had begun at the very onset of Islam with the 'declaration of war' through letters purportedly sent by the Prophet Muhammad to the Byzantine emperor and other rulers, calling on them to 'resign or submit'. A 'first wave' of attack on Europe had been launched by Arab Muslims, a second by the Ottoman Turks and now, in the eyes of a 'fanatical and resolute' minority of Muslims (in the eyes of Professor Lewis), a 'third wave' is underway. 'We should not delude ourselves as to what it is and what it means. This time it is taking different forms and two in particular: terror and migration'. And this time it might be 'third time lucky' for the Muslims.

Islam and Europe was also the theme of the lecture given by Pope Benedict XVI at the University of Regensburg on 12 September $2006 .{ }^{21}$ His starting point was a conversation between the Byzantine emperor Manuel II Paleologus and an unnamed educated Muslim Persian late in the 14th century. The subject matter was Christianity and Islam. For the Pope the early injunction against compulsion in religion is outweighed by what he understands of jihad. On the question of the relationship between religion and violence he quotes the Emperor as saying: 'Show me just what Mohammed brought that was new, and there you will find things only evil and inhuman, such as his command to spread by the sword the faith he preached'. The Emperor goes on to explain why spreading the faith through violence is unreasonable:

God ... is not pleased by blood and not acting reasonably ... is contrary to God's nature. Faith is born of the soul, not the body. Whoever would lead someone to faith needs the ability to speak well and to reason properly, without violence 
or threats... To convince a reasonable soul, one does not need a strong arm or weapons of any kind or any other means of threatening a person with death.

The Pope adds his understanding of the Emperor's statement: 'The decisive statement in this argument against violent conversion is this: not to act in accordance with reason is contrary to God's nature. The editor [of the dialogue between Manuel and his Persian visitor], Theodore Khoury, observes: for the Emperor, as a Byzantine shaped by Greek philosophy, this statement is self evident. But for Muslim teaching, God is absolutely transcendent. His will is not bound up with any of our categories, even rationality'. In another significant passage the Pope writes of the 'inner rapprochement between Biblical faith and Greek philosophical inquiry' as being

an event of decisive importance not only from the standpoint of the history of religions but also from that of world history - it is an event which concerns us even today. Given this convergence it is not surprising that Christianity, despite its origins and some significant developments in the East, finally took on its historically decisive character in Europe. We can also express this the other way around: this convergence, with the subsequent addition of the Roman heritage, created Europe and remains the foundation of what can rightly be called Europe.

Although church spokesmen claimed that he had been misunderstood, the Pope's reproduction and apparent acceptance of one of the main themes of the medieval canon-Islam as a religion of violence - could not but outrage Muslims everywhere. Conversion by force is not sanctioned by Islam. ${ }^{22}$ The secondary argument that, whereas in Christianity to act against reason is to act against the will of God, Islam imposes divine authority on the believer irrespective of reason, is not acceptable to Muslims either. Divine sanction makes no sense in any religion unless the believer bears the responsibility for choosing between good and evil. Responsibility is born of choice, choice is born of reason and reason is born of rationality. Finally, nowhere in his speech does the Pope reflect on the similarity between the two religions in their interface with philosophy.

The Pope's emphasis on the Christian-Greek-Roman roots of European identity seemed to reinforce the view he had expressed in 2004 when, as Cardinal Ratzinger, he said that Turkish membership of the EU would be a 'grave error against the tide of history'. Rather contradictorily, during his visit to Istanbul in November 2006, Pope Benedict was reported to have expressed support for Turkey's admission to the EU on the basis of what a Vatican spokesman (but not the Pope himself) described as 'common values and principles'. ${ }^{23}$ In fact, after years of being delayed, and of seeing other countries being pushed to the head of the membership queue, many Turks had by this time lost hope in the possibility of EU admission whether the Pope supported it or not. In a frank interview with Der Spiegel, Prime Minister Erdoğan observed that support for membership among Turks had dropped in the past two years from $70 \%$ to $30 \%$. 
If you ask if they want Turkey to become a EU member, 60 to 65 per cent still say yes. But if you ask 'Do you believe Europe will accept Turkey?' 60 per cent say no... One could set 2014 or 2015 for our accession to the EU, but above all I am calling on the EU to be honest. If the EU doesn't want us they should say it now and clearly. If we are not wanted then both sides don't need to waste their time with negotiations. Is Europe a home for an alliance of civilizations or is it a Christian club? If the former is true then Turkey should be part of it. ${ }^{24}$

The signs are not promising. Germany's Chancellor Merkel believes the European relationship with Turkey should be limited to a 'privileged partnership' and the election of Nicolas Sarkozy (who in 2005 described rioting young French Muslims as 'scum') has greatly strengthened the antiTurkish camp. 'I have not changed my mind', he told Le Figaro after the election. 'Turkey has no place in Europe. ${ }^{25}$ For the EU's Enlargement Commission, Ollie Rehn, a 'clash of civilisations' would indeed result if $\mathrm{Mr}$ Sarkozy succeeded in blocking Turkey's accession. ${ }^{26}$

\section{Discovery}

The Dialogue, Alliance and Coexistence Between Civilisations all seem implicitly to accept the foundation on which the notion of an impending 'clash' is constructed, ie the division of the world into separate civilisations. Among 'civilisationalists', from Arnold Toynbee onwards, typologies, classifications, criteria and numbers differ but whether there are numerous civilisations or just 'one universal civilization', as the 19th century French historian François Guizot believed, ${ }^{27}$ what is not in doubt is the instrumental use of the word 'civilisation' to justify invasion, conquest and genocide down through the centuries. Neither is there any doubt of the interdependence of civilisations through trade, diplomacy and the exchange of knowledge. They are not and probably never have been self-contained. Martin Bernal has written extensively on the Afro-Nilotic input into 'western civilization' during its 'classic' (Greek) period, ${ }^{28}$ while John Hobson has drawn attention to 'western' borrowings, scientific, technical and intellectual, from 'eastern' (primarily Chinese, Indian and Muslim Arab) societies. ${ }^{29}$ Hamilton Gibb, the pre-eminent western scholar of Islam in the first half of the 20th century, underlined in his studies the interdependent nature of so-called Western and Islamic civilisations at all levels, scientific and intellectual: 'on this point there can be no doubt - that the civilization of the Middle East and that of the socalled 'Western' world are closely related; both before and after the rise of Islam there had been inter-penetration between them'. ${ }^{30}$ States were also similar in the way they were governed. With some exceptions in both categories, the 'Islamic state' was no more of a dogmatic state than the 'Christian' state. Such statements as the 'often-noted lack of a tradition of secular politics' in Muslim histories ${ }^{31}$ are not borne out in the way Muslim governments were actually run. Philip K Hitti drew attention a long time ago to the essentially secularised nature of the Arab caliphates as far back as the Umayyad khalifa Mu'awiyya. ${ }^{32}$ The Ottoman state commonly described as 
an 'Islamic state' was in fact a hybrid in which religious law and Ottoman traditions together formed the basis of government and administration. All these states were run according to the same pragmatic conventions of dynastic succession and statecraft as nominally Christian states, further reducing the ostensible differences between Western and Islamic civilisations. By any reasonable standard of piety, many of their rulers could not even be regarded as 'good' Muslims (any more than some 'Christian' kings and princes could be said to be 'good' Christians). Dogma followed statecraft, with religion utilised to provide the justification for wars, peace, the acquisition of territory and the signing of treaties and the establishment of diplomatic relations.

If the 'Islamic' state was not truly Islamic, and the 'Christian' state not truly Christian, with rulers bending the rules to suit their interests; if civilisations are not separate but interdependent; if 'Christianity' was constructed by the church as an institution to serve its interests, and utilised by the 'Christian' state to serve its interests; if 'Islam' has been constructed as a monolith by the West to create an enemy it needed; if the West is itself no more than a concept, summoned into life in 1945 to justify ideological and strategic confrontation with a Soviet East, in the name of defending 'Western interests' that were actually the interests of specific governments, then the civilisational debate indeed assumes a spectral quality.

If what has been taking shape over many millennia is not the development of separate civilisations but the rise of a world system, ending up in the past half millennium as Immanuel Wallerstein's world capitalist system, then the 'dialogue of civilisations' indeed becomes no more than 'an ideological formula which, in the message of tolerance and relativism it conveys, betrays a choice to reject the unitary nature of the world we live in'. In the words of Cağlar Keyder:

It adheres to a model of the world where conflict is between monolithic civilizations and [it] makes the inequalities and hierarchies within the unique world system, whose workings are the dominant cause of conflict, difficult to see. Especially when any aggression is packaged in terms of irreconcilable conflict among civilizations and any challenge to power is presented as evidence that there is a clash of civilizations, there is a responsibility to expose the rhetoric and to struggle against the imposed agenda. There has been a single world civilization at least since the expansion of the West started five hundred years ago. ${ }^{33}$

If the ultimate source of the world's problems lies in the failings of the world system, measured against the rights and needs of the overwhelming bulk of the world's people, and not in a 'clash of civilisations', then the Dialogue of Civilisations can hardly be the answer: like the 'clash of civilisations', it has the potential to turn into a well publicised distraction which diverts attention from the true sources of the most pressing transnational problems as they affect Muslims

\section{Reality check}

In the world system the exercise of military, economic and diplomatic power has been the privilege of the West in its different religious, national and 
imperial incarnations for the best part of half a millennium. This is the period Bernard Lewis now sees as coming to an end. ${ }^{34}$ In fact the power of the amorphous West is the power of particular governments, expressed unilaterally and multilaterally in all global organisations, including the IMF, the World Bank, the United Nations and the G8. These organisations are no more than the sum of their parts, their decisions weighted in favour of the most powerful. The decision to partition Palestine in 1947 is a prime example of how the UN was corrupted by power within two years of its foundation. In effect, it was not the General Assembly which decided that Palestine should be partitioned but President Truman, who orchestrated a campaign of intimidation of vulnerable governments from behind the scenes to make sure that the resolution got over the line. Without this interference, undertaken to boost Truman's electoral standing at home, it would never have been passed.

In democratic systems there is no parliament as incongruous as the world parliament represented by the General Assembly and the Security Council. In this parliament it is the lower house that has advisory power and the upper house that exercises such real power as the world body has. In recent years the Security Council has been frequently used to give the imprimatur of UN endorsement to actions that would never have been supported by the majority of its members. The power of the five permanent members of the Security Council resembles the power of Plato's Nocturnal Council or the power of Iran's Council of Guardians over the majlis. This is hardly accidental. The League of Nations was constructed to give the strongest hand to its most powerful members and so was the United Nations. The theory that they would act more responsibly has been exploded time after time. It was with the authority of the council that a decade of sanctions was maintained against Iraq after the invasion of Kuwait in 1990 and the US-led counter-attack on Iraq early the following year. The catastrophic humanitarian consequences (with hundreds of thousands of children among the one million people dying as the direct or indirect result of the denial of essential services and goods) represented serial breaches of the UN's own conventions and treaties. Behind the façade of the council's authority lay the determination of the US and British governments to see that sanctions were maintained against a rising tide of world opposition based on revulsion at what was being done to Iraq in the name of disarmament.

The Security Council is also to be judged by what it chooses not to do. In international law there is surely little difference between Iraq's invasion of Kuwait in 1990 and the US-led invasion of Iraq in 2003, but there was certainly a difference in how the Security Council reacted. Iraq was censured and subjected to sanctions within days, whereas the actions of the USA and its war partners, far from being censured, were actually endorsed through the Security Council's approval of the establishment of a government of occupation (the Coalition Provisional Authority) and through the passage of a resolution (in June 2004) miraculously transforming the invading forces into a 'multinational force'. Since March 2003, the birthplace of civilisation - the Land of the Two Rivers-has been subjected to what is most 
probably the greatest level of death, dislocation and destruction in its multimillennial history, and yet the Security Council has raised its voice only to put its stamp of approval on the invasion. Forty years have now passed without sanctions being applied against Israel for its occupation of Palestinian and Syrian territory seized in 1967 (not to speak of the territory seized in 1948 in breach of the partition plan). The expansion of Jewish settlements towards the Jordan river continues with the tacit support of the US administration. The persecution and ethnic cleansing of Palestinians in Hebron is itself sufficient cause for the Security Council to take action, yet it does nothing and can do nothing because any resolution will run up against the barrier of the US veto.

These anomalies scarcely go unnoticed in the Muslim world. In summer 2006 the Security Council failed to react during Israel's onslaught on Lebanon because the Bush administration would not allow it to call for a ceasefire. It held Israel's coat for week after week in the hope that the Israeli military machine would destroy Hizbullah. The outcome (without Hizbullah being destroyed or Israel's captured soldiers being released) was the destruction of roads, bridges, power stations, fuel storage depots and apartment buildings. Cluster bombs were scattered over villages and fields of southern Lebanon. About one third of the 1400 Lebanese civilians killed were children, with entire families obliterated in their homes by Israel's 'defence' forces without the Security Council intervening. The manipulation of the council by the USA in an attempt to force Iran to forego nuclear development is a further example of how it has become a political tool in the hands of the permanent members rather than developing into an instrument for keeping world order. Sanctions invoked in the name of the Security Council may yet be used to justify a military attack on Iran as well.

\section{Morally ambiguous}

The role of the Secretary-General in directing this morally ambiguous universe called the UN is obviously critical. Kofi Annan launched the Alliance of Civilisations and has since remarked that the UN 'can be the true home of the dialogue among civilizations' and 'the place where such dialogue can flourish and bear fruit in every field of human endeavor' ${ }^{35}$ These noble sentiments are not to be decried. However, if the UN is to be improved not just as a forum for dialogue, but as one in which dialogue is organically linked to decisions and action, it urgently needs reform. It is clearly falling far short of the ideals embedded in the charter, and the way the Secretary-General discharges his responsibilities is regarded by many as part of the problem.

$\mathrm{Mr}$ Annan filled the office from 1997 until his retirement in 2006. His predecessor was Butros Butros Ghali, the former Egyptian foreign minister and an 'enlightened' conservative who had overseen the publication of two major UN reports, Agenda for Peace and Agenda for Development. ${ }^{36}$ His Arab world perspective and Third World orientation soon put him at loggerheads with the USA, which had been lukewarm about his appointment in the first place. He criticised the NATO bombing of Serbia, and indeed the 
US preoccupation with southeastern Europe, at a time genocide was being committed in Rwanda and Somalia was gripped by famine. In 1996 the inquiry he ordered into the Israeli bombardment of the UNIFIL compound at Qana in southern Lebanon on 18 April brought matters to a head. Video film shot by a Norwegian soldier showed an Israeli pilotless drone flying over the compound before and during the bombardment, undermining the Israeli claim that the shelling in which 106 Lebanese men, women and children were killed was accidental. After pressure from the USA Butros-Ghali released a 'carefully edited' version of the critical findings of the committee sent to Qana, but it was still strong enough to seal his fate as far as the US administration was concerned. ${ }^{37}$ When his mandate came up for renewal later in 1996, senior US officials working under the instructions of the US Secretary of State, Madeleine Albright, set in motion 'Operation Orient Express' to ensure that it would not be renewed. ${ }^{38}$ The Secretary-General's reappointment was supported by all members of the Security Council but one, and after the USA had vetoed the results of seven ballots in his favour the council voted for Kofi Annan. With his appointment, remarked one Bush administration official, the USA now had a Secretary-General able 'to understand the importance of cooperation with the world's first power'. ${ }^{39}$

Under the UN Charter (Article 100), 'each member undertakes to respect the exclusively international character of the Secretary-General and the staff and not to seek to influence them in the discharge of their responsibilities'. For their part, the Secretary-General and his staff are obliged to refrain 'from any action which might reflect on their positions as international officials responsible only to the Organisation' (article 100). The Secretary-General is described in the UN Charter as the organisation's 'chief administrative officer', when he is clearly much more than that. The position of SecretaryGeneral implies a moral purpose. Just as the efficient manager is expected to ensure that his company's products are produced to the highest possible material standards, so the Secretary-General has the putative responsibility of seeing that the moral output of the UN meets the criteria that have been laid down in the Charter and in the international covenants that are the foundation of the organisation's work. It is in this context that Mr Annan has been criticised, especially for not speaking out against the breaches of the UN charter represented by NATO's air attack on Yugoslavia in 1999 and by the US-led invasion of Iraq in 2003. The Security Council's imprimatur on a decade of sanctions and its inaction in the face of the invasion links up with the suicide bombing of the UN headquarters in Baghdad in which Sergio Vieira de Mello, the Secretary-General's Special Representative in Iraq, and many of his staff were killed. In the words of Alvaro de Soto, the SecretaryGeneral's Personal Representative to the PLO and the Palestinian Authority as well as Special Co-ordinator of the Middle East Peace Process (MEPP): 'The UN deployed there in circumstances under which the UN does not normally operate. Does anyone doubt that the attack took place because the UN was seen to be under the aegis of those who are seen by the perpetrators as the occupiers? Am I mistaken in believing that the UN was attacked as the proxy for the real target under whose auspices the UN was there?'. ${ }^{40}$ 
For its insights into the realities of power at the highest level of UN operations, the leaked confidential report issued by Alvaro de Soto on his tenure in office has few rivals in recent history and is worthy of detailed consideration for that reason. Mr de Soto's peace-process-related terms of reference included Israel, Egypt, Syria, Lebanon, Jordan and the further Palestinian territories seized by Israel in its war of 1967. Shortly after his appointment in May 2005, the Middle East political map was transfigured by three developments: first, Israel's unilateral withdrawal of its settlers from Gaza (August, 2005); second, Ariel Sharon's stroke and abrupt disappearance from the political scene (January 2006); and third, the electoral victory of Hamas over Fatah in the Palestinian elections (January 2006). The 'Quartet' (the USA, EU, UN and Russia) had been given the task of pushing forward the 'peace process' and was of its nature immediately engaged in all of these events. James Wolfensohn, former president of the World Bank, was designated the Quartet Special Envoy for Gaza Disengagement, 'with a mandate to revitalize the Palestinian economy which had gone stagnant since the closure system was tightened at the beginning of the second intifada'. ${ }^{41}$ After a brisk start Wolfensohn's mission began to run aground. His attempts to establish an agreement on access and movement

were intercepted - some would say hijacked - at the last minute by US envoys and ultimately [US Secretary of State Condoleezza] Rice herself. While the Agreement on Movement and Access (AMA) of 15 November, 2005, was painstakingly cobbled together by Wolfensohn and his high-powered team in the previous months, key alterations were made at the eleventh hour and he was virtually elbowed aside at the crowning moment. From that moment on his star in the Middle East peace process firmament began to dim and a few months later it disappeared altogether when he testified in the US Congress in a way that left little uncertainty as to his disgruntlement and who he blamed. In the event he left the scene with a more jaundiced view of Israeli (and US) policies than he had upon entering. ${ }^{42}$

Ariel Sharon's true intentions were clear. Disengagement was no more than a means of putting the 'road map', agreed upon by the Quartet in April 2003, in 'formaldehyde' so that behind the well publicised façade of commitment to the 'peace process' his government could continue to build settlements and its 'security wall' on the West Bank without interruption. Israeli troops and settlers were withdrawn from Gaza, but the territory remained blockaded from land, sea and air, economically throttled and subject to frequent devastating military attacks. The adverse Western reaction to the election of the Hamas government was to greatly worsen the situation. In September 2005, the Quartet had agreed to a formula (announced by Kofi Annan) which included the position that 'the forthcoming Palestinian legislative election should be seen as a stage in the Palestinian evolution towards democracy', and that the question of participation should be left to the Palestinians themselves, notwithstanding the 'fundamental contradiction' between participation in elections and possession of militias. ${ }^{43}$ All parties (including Israel) 
were called on to respect the results and co-operate with the Palestinians. The implicit basis of this approach was the assumption that Fatah would retain its majority in the Palestinian legislature. In the event it was Hamas which won a resounding victory. The day after the election the Quartet issued a statement asserting that 'a two-state solution to the conflict requires all participants in the democratic process to renounce violence and terror, accept Israel's right to exist and disarm as outlined in the Road Map'. ${ }^{44}$

In fact, as the so-called Road Map had already been comprehensively violated by Israel, the Hamas government would seem to have been justified in asking which Israel it was expected to recognise, the state envisaged within the partition lines of 1947, the state which came into existence in 1948 or the state which seized the rest of Palestine in 1967 and was still proceeding with its colonisation four decades later. When Hamas refused to yield before the Quartet's demands Gaza was placed under full economic blockade, including the retention by Israel of taxes needed to pay the salaries of employees of the Palestinian Authority and to fund the operation of hospitals and schools, while being subjected to the destruction of infrastructure and killing of civilians by Israel's armed forces throughout 2006. Israel's behavior again raised the question of the Security Council's inaction in the face of serious, continuing violations of the UN's own treaties and conventions. The blockade was 'never intended' by three members of the Quartet but was imposed on it by the USA. ${ }^{45}$

Summarising his experiences, Alvaro de Soto writes that 'whatever the Quartet was at the inception, let us be frank with ourselves: today, as a practical matter, the Quartet is pretty much a group of friends of the US and the US doesn't feel the need to consult closely with the Quartet except when it suits it'. Indeed, the 'peace process' as its affects the entire Middle East 'has become strategically subservient to US policy' ${ }^{46}$ — which actually means, as US policy almost never deviates from Israeli policy, subservient to Israeli policy. In its statement of 2 February 2007 the Quartet called on all parties to the 'peace process' to 'refrain from taking any measures that could predetermine the number of issues that will be resolved in negotiations, without mentioning what Alvaro de Soto calls Israel's 'total non-compliance' with the Road Map, requiring it to freeze settlement activity, dismantle 'unauthorised' settler outposts (presumably as opposed to authorised illegal settlements and outposts) and allow the opening of Palestinian institutions in East Jerusalem. By the time this statement was issued, the supposed 'evenhandedness' of the Quartet, which could hardly be taken seriously at the outset and had been increasingly exposed as sham in the previous two years, had been 'pummeled into submission in an unprecedented way'. ${ }^{47}$

\section{Imprimatur}

The Secretary-General was caught between what he was supposed to do in the name of upholding the UN Charter and what powerful members of the UN wanted him to do. By issuing statements prepared by the Quartet he gave 'the appearance of an imprimatur on behalf of the international community', 
when in fact the Quartet was continually taking positions that would not find majority support within the General Assembly or the UN's specialised agencies and appeared, in Alvaro de Soto's words, 'to fall short of the minimum of even-handedness that must be the lifeblood of the diplomatic action of the Secretary-General'. The blockade of Gaza, with the EU lining up in support of the US-Israeli position that there could be no negotiations with the Hamas government unless it recognised Israel, again compromised the UN. In the view of Alvaro de Soto, the positions taken by the Quartet since the end of 2005 'led the UN on to thin ice and put personnel in the field in the uncomfortable position of trying to alleviate the "siege" [of Gaza] while being seen as one of those who have imposed that siege or at least having condoned it and also as part of the international effort to maintain it'.

On the broader question of negotiations with all parties involved in the 'peace process', pressure by the USA from behind the mask of the Quartet prevented Alvaro de Soto from making contact with Syria and the Hamas government. Under the guidelines issued by the Secretary-General, UN agencies were allowed to maintain such contacts as were necessary for their work in the field, but high-level political contacts could only be made with Mr Annan's authority. In the case of Alvaro de Soto, these were never allowed, the suggestion being allowed to hang in the air that they would breach Quartet 'policy' and cause difficulties in relationships between members. Besides two telephone calls on the specific instructions of the Secretary-General and a chance encounter during a meeting with President Mahmud Abbas, de Soto had no contact with the Palestinian prime minister (Ismail Haniyya) or with any member of his elected government before the formation of a Government of National Unity in 2007. Neither was he able to initiate a dialogue with Syria. These were all opposed 'by HQ' - in other words, by Kofi Annan.

As only one member of the Quartet actively opposed contact with the Hamas government, 'the leadership of the PA government might justifiably wonder whether that member isn't behind the decision of the SecretaryGeneral to ostracise that government'. In the case of Syria, its government 'might be forgiven for wondering whether the Secretary-General's policy is inspired not by international law including Security Council resolutions but by the bidding of one or two permanent members of the Council'. The implications for the credibility of the UN and the humanitarian work of its specialised agencies were clear. A Secretary-General who compromises the independence of his role as outlined in the UN Charter

will do so at the peril of the continued exercise of that role and the cause of peace in conflicts where he can actually make a difference... the practical translation of the above is that if the Secretary-General is swayed, or is seen to be swayed, by one or the other Member State, other members, and indeed any party to a conflict susceptible of being entrusted to the Secretary-General's good offices, will justifiably hesitate to deposit that trust in him.

The question arising is whether the Secretary-General discharges his duties independently, 'having regard only to the law, the Charter, Council 
resolutions and his own judgment of what is right for a solution of the ArabIsraeli conflict', or whether he provides 'an alibi for a wider strategy which hasn't been espoused by the Security Council'. But, as was pointed out earlier, powerful actors or one powerful actor will only support the appointment of a Secretary-General who 'understands the importance of cooperation with the world's first power'. Sir Mark Malloch Brown, the conservative former Deputy Secretary-General to Kofi Annan, has remarked that 'I have seen the [humanitarian] work I used to do get steadily more dangerous as it is seen as serving Western interests rather than universal values'. For international aid workers to be seen as neutral, their work 'must be separated from the US-political and security process and must be there in its own right'. 48

\section{'Out of balance'}

In its Final Report the High-Level Group of the Alliance of Civilisations noted that the world was 'alarmingly out of balance', that it was characterised by 'great inequalities and paradoxes' and that the anxiety and confusion created by the 'clash of civilisations' theory 'has distorted the terms of the discourse on the real nature of the predicament the world is facing'. ${ }^{49}$ Futhermore:

there is a growing perception that universal principles of human rights and democratic governance are only vigorously defended in those cases where they are viewed by some states to be in their interests - a selective approach that undercuts the legitimacy of the multilateral institutions mandated to articulate, advance and advocate for those principles. Eloquent statements in support of democracy lose their relevance when democratically elected governments are shunned and sometimes subverted by powerful governments. ${ }^{50}$

The report dilates on extremism and terror, concluding that the only durable solution lies 'in addressing the roots of the resentment and anger that makes exclusivist and violent ideologies attractive in the first place' and emphasising the central role that must be played by the UN. The guiding principles set out by the High-Level Group include 'adherence to international law and covenants including all rights and responsibilities governing the conduct of war as articulated in International Humanitarian Law (particularly the Geneva Conventions), respect for the institutions that establish them and support mechanisms that adjudicate violations of these norms'. A 'full and consistent adherence to human rights standards forms the foundations for stable societies and peaceful international relations', and therefore is part of what is needed for the world to regain its lost balance. Terrorism can never be justified, according to the report, which notes that non-state actors are not alone in employing terrorist methods, giving as examples Nazi Germany, the USSR, Cambodia (under the rule of Pol Pot) and governments in the Balkans. (Readers would obviously add to this list according to taste.) Under the heading of 'Relations between Societies of Western and Muslim Countries', the report turns to what virtually every document on dialogue 
or alliance of civilisations agrees is a central cause of tension between the two groups (as defined), the Israeli-Palestinian conflict. The causes of Muslim resentment are briefly described. Israel's occupation of Palestinian and other Arab territories; the 'unresolved' status of Jerusalem; the 'perceived' acquiescence of Western governments in the Israeli occupation; the Muslim perception that the occupation is a form of colonialism; the Muslim perception that the West and Israel collude; and the Muslim perception of double standards in the application of international law.

The report calls for a non-violent solution ending in a 'viable' Palestinian state living alongside Israel (not a state formed within the boundaries of presently occupied territory), suggesting that 'the terms of reference agreed to by all parties at the Madrid conference in 1991, the peace initiative by President Clinton in 2000 and the peace proposal by the Arab League at its meeting in Beirut, Lebanon, in 2002, make it clear that the framework for a broad-based accord does exist and the political will can be generated'. To further this process, there should be "mutual recognition of the competing narratives' that are 'mirrored in divergent interpretations of recent history' and 'different ways of describing conflicts, occupation and peace negotiation efforts'. The High-Level Group would like to see a White Paper being prepared on Palestine which 'would make it clear to the Palestinian people that the price of decades of occupation, misunderstanding and stigmatization is being fully acknowledged while at the same time contributing to exorcize the fears of the Israelis'.

There is much to be said by way of criticism about the way the HighLevel Group has framed this issue. Palestine is not just an issue between Muslim societies and so-called Western societies. It is an international legal and human rights issue that cuts across national and cultural boundaries. Palestinian and other Arab Christians and many people in the so-called West who are not Muslims have just as strong feelings about it as Muslims do. There might be a clash of interests on this issue but there is certainly no 'clash of civilisations'. The colonisation of the territories seized in 1967 (including East Jerusalem) is not really a matter of 'perception' by Muslims or anyone else but a matter of fact (except in the eyes of the settlers and their supporters). The settlers have been moved into these territories in clear violation of the laws of war. The references to 'competing narratives' and 'divergent interpretations' suggest a symmetry between occupier and occupied, undermining the Palestinian situation according to the same UN resolutions and conventions the High Level Group says must be upheld. Collusion, acquiescence and double standards are not Palestinian or Muslim 'perceptions': they accurately describe Western behavior in the Middle East from the end of the First World War up to the present.

The 'peace process' set up at Madrid did not reveal that 'the framework for a broad-based accord and the political will does exist'. It revealed the very opposite. The Madrid framework for peace was built on the deliberate and specific avoidance of international law as it related to the rights of the Palestinians. It is not without reason that the Palestinians regard the "peace 
process' as one of the greatest disasters to befall them since 1948. Israel's continued colonisation of Palestinian and Syrian territory and its refusal to consider Arab offers of peace in return for withdrawal are clear signs that the political will is a long way from being generated. The High-Level Group's claim that the 'price' the Palestinians have had to pay is being 'fully acknowledged' is unsupportable if not completely meaningless, even insulting to the intelligence, against the background of settlement expansion towards the Jordan river, the ethnic cleansing of Hebron, the killing of thousands of Palestinian civilians by Israel's 'defence forces' and the blockade of the democratically elected Hamas government by Israel, the USA and the EU from the beginning of 2006. The claim that the Annapolis international conference (November 2007) provided 'another push to the resolution of the Arab-Israeli conflict ${ }^{51}$ is not shared in the Middle East, where it was widely seen as just another photo opportunity in the continuing attempt to impose a settlement on the Palestinians.

It is equally hard to reconcile the situation in Gaza and the West Bank with the claim that the 'international community', with 'a view to healing the deep scars of the recent past, has been desperately searching for ways to address emerging threats emanating from hostile perceptions of other cultures and civilisations'. ${ }^{52}$ Nowhere do the scars run deeper than in Palestine, yet even now the same 'international community', broadly speaking, that voted for the partition resolution of 1947 and thereby condemned the Palestinians to six decades of torment (so far) is refusing to take responsibility for the consequences of its actions. It has steadfastly refused to consider a solution based on the rights granted to the Palestinians under international law. Nowhere in the West, in its individual governments, regional blocs and the multinational organisations it dominates, is there any sign of a principled response to the abuse of international law represented by the conquest and continuing settlement of Palestinian and other Arab territories. How is 'dialogue' going to change this situation?

Governments, NGOs and inter-faith organisations scarcely need any reminders of the importance of dialogue in bridging cultural gaps and building more harmonious societies. It is an essential tool of social harmony everywhere, but the central problems of the Middle East affecting its relationship as a region with the West are rooted in breaches of international law and the power politics of sovereign states. Governments that live in wilful violation of the law, and the governments that support them for political or strategic reasons of their own, are not likely to be persuaded to change their ways through 'dialogue' unless it is backed by the determination to punish those who break the law, if the breaches are serious enough, through sanctions and isolation from international organisations. Where dialogue is not the problem it cannot be the solution. To be effective, both 'alliance' and 'dialogue' must be prepared to put forward concrete solutions to global problems that challenge the structures of power and self-interest. Is there any chance that they will be accepted? This would seem to be the central dilemma in a world beset by problems that are only symptoms of a deeper malaise. ${ }^{53}$ 


\section{GLOBAL DISORDER AND THE LIMITS OF 'DIALOGUE'}

\section{Notes}

1 Samuel P Huntington, 'The clash of civilizations?', Foreign Affairs, 72 (3), 1993, pp 22-49.

2 Samuel P Huntington, The Clash of Civilizations and the Remaking of World Order, New York: Simon and Schuster, 1996.

3 In discussing the civilisational debate in this article, I have drawn on an early chapter in my forthcoming book, The Unmaking of the Middle East: A History of Western Disorder in Arab Lands, Berkely, CA: University of California Press, 2008.

4 See discussion with Elizabeth Wasserman, 'Islam's interpreter', The Atlantic Unbound, 29 April 2004, at http://www.theatlantic.com. Lewis has repeated the line in other interviews.

5 Bernard Lewis, The Arabs in History, London: Hutchinson's University Library, 1954, p 178.

6 Bernard Lewis, The Middle East and the West, London: Weidenfeld and Nicolson, 1964, p 135.

7 Ibid, p 137.

8 Bernard Lewis, 'The roots of Muslim rage', Atlantic Monthly, 266 (3), 1990, pp 47-60.

9 Bernard Lewis, Islam in History: Ideas, People and Events in the Middle East, Chicago, IL: Open Court Press, 1993, p 410.

10 Quoted by Ian Buruma in his review of the Lewis book, From Babel to Dragomans. See Buruma, 'Lost in translation: the two minds of Bernard Lewis', The New Yorker, 14-21 June, posted online on 6 June, at http://www.newyorker.com.

11 Sir William Muir, The Life of Mahomet from Original Sources, London: Smith, Elder and Co, 1878, p 535.

$12 \mathrm{Mr}$ Zapatero was speaking during a session of the UN General Assembly in September 2004.

13 For background, see 'The co-existence expedition, at http://www.co-existence.org.

14 Quoted in 'Erdoğan calls on EU to help global peace', Today's Zaman, 16 January 2008, at http:// www.todayszaman.com/tz-web/detaylar.do?load=detay\&link $=131753$.

15 Jorge Sampaio, 'Alliance of civilisations', Al Ahram Weekly, 25 January 2008, at http://weekly. ahram.org.eg/print.2008/881/op23.htm

16 Flemming Rose, 'Europe's politics of victimology', Blueprint, 17 May 2006, at http://www.ndol.org.

17 Ibid.

18 Dr Heba El-Kholy, UN Resident Co-ordinator and UNDP Resident Representative in North Africa, speaking at a forum on 'The Euro-Mediterranean Political Challenges', Brussels, 7 December 2006. For full text, see http://www.unictunis.org.tn.

19 See the statements by a former Archbishop of Canterbury, Lord Carey, and by Cardinal Cormac Murphy-O'Connor, in 'Sharia law may result in legal apartheid', Daily Telegraph, 10 February 2008, at http://www.telegraph.co.uk.

20 See the 2007 Irving Kristol lecture by Bernard Lewis, American Enterprise Institute, Washington, DC, 20 March 2007, at http://aei.org.

21 Pope Benedict XVI, 'Faith, reason and the university: memories and reflections'. For full text, see http://www.vatican.va.

22 The extent to which it might have happened, especially after the fury of a battle, is a separate matter for debate.

23 See Reuters report published under the heading 'Pope defuses tensions on visit to Turkey', ABC News Online, 29 November 2006, at http://www.abc.net.au.

24 Interviewed by Annette Grossbongardt and Joachim Preuss in Ankara, Der Spiegel, 16 April 2007. Full text in English at http://acturca.wordpress.com.

25 'Interview with French President Nicolas Sarkozy', at http://www.lefigaro.fr/english.

26 See 'Rehn warns of clash if Sarkozy blocks Turkey', Today's Zaman, 12 June 2007, at http:// www.todayszaman.com.

27 Peter Burke (ed), A New Kind of History: From the Writings of Febvre, London: Routledge and Kegan Paul, 1973, p 241

28 Martin Bernal, Black Athena: The Afroasiatic Roots of Classical Civilisation, 2 vols, New Brunswick, NJ: Rutgers University Press, 1987.

29 John M Hobson, The Eastern Origins of Western Civilisation, Cambridge: Cambridge University Press, 2004.

30 HAR Gibb, Studies on the Civilisation of Islam, eds Stanford J Shaw \& William R Polk, London: Routledge and Kegan Paul, 1962, p 324.

31 Francis Fukyama \& Nadav Samin, 'Can any good come of radical Islam? A modernising force? Maybe' (Opinion Journal), Wall Street Journal, 12 September 2002, at http://www.opinionjournal. com.

32 Philip K Hitti, A History of the Arabs, London: Palgrave Macmillan, 2005, p 441.

33 Cağlar Keyder, 'Dialogue Among Civilisations?" Background Paper (BP8), 28 July 2005, European Commission's Advisory Group on Social Sciences and Humanities in the European Research Area, at http://ec.europa.eu. 
34 'There are times in the long history of the human adventure when we have a real turning point, a major change - the end of an era, the beginning of a new era. I am becoming more and more convinced that we are in such an age at the present time - a change in history comparable with such events as the fall of Rome, the discovery of America and the like.' Lewis, Irving Kristol lecture.

35 See Mr Annan's address to Seton Hall University's School of Diplomacy and International Relations in South Orange, NJ, 5 February 2001, at http://www.un.org.

36 See Eric Rouleau, 'Why Washington wants to oust Mr Boutros Ghali', Le Monde Diplomatique, November, 1996, English translation and summary published on Global Policy Forum, at http:// www.globalpolicy.org.

37 See Phyllis Bennis, 'Veto', The Link, January-March 2003, p 9, at http://www.ameu.org.

38 Perry Anderson, 'Made in USA', The Nation, 2 April 2007, at http://www.thenation.com.

39 Ibid, quoting Assistant Secretary of State James Rubin.

40 See Alvaro de Soto, 'End of Mission Report', May 2007. The report can be downloaded from various sites, including that of the Guardian. See 'Secret report condemns US for Middle East failures', Guardian, 13 June 2007, at http://www.theguardian.co.uk.

41 Ibid.

42 Ibid.

43 Ibid.

44 Ibid.

45 Ibid.

46 Ibid.

47 Ibid.

48 Ann Penketh, 'UN no longer seen as neutral says former chief', Independent, 25 June 2007, at http:// news.independent.co.uk.

49 'Alliance of Civlisations, Final Report of the High-Level Group', 13 November 2006, at http:// www.un-ngls.org/site/IMG/pdf/Final_Report.pdf.

50 Ibid.

51 Mahmood Ayub, UN resident co-ordinator in Turkey, 'Alliance of civilisations aims to celebrate diversity', Today's Zaman, 16 January 2008, at http://www.todayszaman.com/tz-web/detaylar. do?load=detay\&link $=131713$.

52 Ibid.

53 A large volume of material has been published on and offline on the questions of alliance of civilisations and on related matters. Apart from the references in this article, valuable sources include material available on the UNESCO website (http://portal.unesco.org) and on Reset (http:// www.resetdoc.org; the publications of the Strategic Foresight Group of Mumbai, especially its monograph by Sundeep Waslekar, An Inclusive World, 2007; reports of the Pew Research Centre, especially An Uncertain Road: Muslims and the Future of Europe (October 2005) and The Great Divide: How Westerners and Muslims View Each Other (June 2006), a report on a 13-nation attitudes survey; a Chatham House address by former Iranian president Muhammad Khatami ('Tolerance, moderation and the dialogue of civilisations', 1 November 2006); and a CNN interview with Mr Khatami, 7 January 1998, at http://www.cnn.com.WORLD9801/07/iran/interview.html. 